learn rule-governed behaviour, does reinforcement provide a fully adequate explanation of all that is going on in the process?

If such language is used, why not use a cognitive model that makes such lapses unnecessary? The concept of "self-system" can cover the phenomena with which Rachlin is concerned and much else besides, and recent studies of the "self" (Baumeister 1999) are generating an approach which is as hard-headed as teleological behaviourism. Rachlin uses the "self" only as "existing contingently in a series of temporal intervals during which behavior occurs in patterns" (sect. 4), a model that he suggests would imply that people's selves evolve and change. But of course they do. It is well established that the "self" (in the sense of a self-description) changes with age and context (Harter 1998; McGuire \& McGuire 1988). Rachlin seems unaware of recent developments in this field.

Self-descriptions include references to moral precepts ("I try to be honest"). It is a not unreasonable suggestion that what we describe as "conscience" involves comparison between past, present, or intended action and the moral code incorporated in the selfsystem (Hinde 2002). This is not incompatible with Rachlin's description of altruism - "What is highly valued is a temporarily extended pattern of acts into which the particular act fits" (sect. 1.2). Even Rachlin postulates a "coherent sense of self" for the maintenance of altruism. This is entirely in keeping with the results of studies of extraordinary individuals who served as exemplars to many. Such individuals had great certainty about the decisions they made, as though morality were completely integrated into the self-system and altruistic actions involved no conflict with other personal motivations (Colby \& Damon 1995; Youniss \& Yates 1999). Indeed, studies of personal relationships in the context of exchange theory suggest that being overbenefited as well as being underbenefited can provoke compensatory behaviour (e.g., Prins et al. 1993). If this is confirmed, it indicates that not only a moral code but a social contract is incorporated in the self-system.

How are moral issues incorporated? Young infants show a great deal of proto-prosocial behaviour - sharing, caregiving, showing sympathy, and so on (Rheingold \& Hay 1980) - as well as selfish or egocentric behaviour. Rachlin rejects the idea of an inherited mechanism for altruism, but the evidence points to a predisposition to learn to please caregivers. Developmental psychologists have shown how prosocial tendencies are moulded through relationships, especially those within the family, and thus come to form part of self-descriptions (Turiel 1998). Yes, of course reinforcement plays a part, but broad moral precepts, like "You should protect others from danger," may be incorporated even if the opportunity to act on it has never occurred. There is no denying that reinforcement may play some role in the genesis and maintenance of (apparent) altruism. Minor altruistic acts often receive nods of approval and may contribute to the actor's status (see discussion of meat-sharing by hunter-gatherers, Hawkes et al. 2001). And reinforcement, if used in a strict Skinnerian sense, is a more hardheaded concept than the "self-system," which still has fuzzy borders. But reinforcement loses its edge if it is pushed beyond its limits. The use of the "self-system" as something more than an intervening variable but perhaps not quite a hypothetical construct (MacCorquodale \& Meehl 1954) can embrace not only the behaviour but also the experience of individuals.

\section{Toward a better understanding of prosocial behavior: The role of evolution and directed attention}

\author{
Stephen Kaplan a and Raymond De Young ${ }^{\mathrm{b}}$ \\ a Departments of Psychology and of Electrical Engineering and Computer \\ Science, University of Michigan, Ann Arbor, MI 48109; b School of Natural \\ Resources and Environment, University of Michigan, Ann Arbor, MI 48109. \\ skap@umich.edurrdeyoung@umich.edu \\ http://www.snre.umich.edu/ rdeyoung
}

Abstract: Rachlin's thought-provoking analysis could be strengthened by greater openness to evolutionary interpretation and the use of the directed attention concept as a component of self-control. His contribution to the understanding of prosocial behavior would also benefit from abandoning the traditional (and excessively restrictive) definition of altruism.

Discussions of altruism routinely exclude from consideration any behavior from which the actor receives pleasure or other benefit. That Rachlin adopts this traditional approach is understandable but unfortunate. In a perceptive and inadequately appreciated analysis, Wallach and Wallach (1983) point out that there are two distinct meanings of self-interest (or, in their terms, "egoism"). In their example, you can be motivated by helping someone because you expect something in return or because "the other person's relief from distress or the other person's happiness is itself what you want to achieve and what would make you happy" (p. 201). As they point out, the two situations are equally self-interested only in the most trivial sense. Yet it is this trivial sense that studies of altruism call upon when they use the traditional definition, that is, that one is acting against one's self-interest. The result is that the enormously important topic of what motivates prosocial behavior tends to be neglected in favor of a focus on special and atypical cases.

Even accepting this limitation, however, Rachlin's argument is flawed by his determination to eliminate the potential role of evolution as a component of altruism. This commitment harks back, unfortunately, to an earlier era, when a then-dominant behaviorism argued that the existence of a behaviorist explanation demonstrated that all other explanations were irrelevant. This notion that an explanation at one level usurps the possibility of a useful explanation at another level has been sufficiently pervasive to have received several colorful appellations, such as "nothingbutism" and MacKay's (1965) more elegant "fallacy of 'nothing buttery'." This way of thinking is no more acceptable now than it was then; if indeed there is a demonstrable role of habit in altruism, this in no way eliminates the possibility that there is a role for evolution as well.

A particularly interesting component of Rachlin's discussion is his use of intrinsic motivation. It is also, however, a topic where a bias against an evolutionary perspective is a serious handicap. His interpretation of intrinsic motivation as arising from a string of habits is less than convincing. The fascination with crossword and jigsaw puzzles seems far more likely to be an expression of the human inclination to solve problems, a tendency humans share with nonhuman primates (Harlow 1953). The very widespread character of this motive strongly suggests its evolutionary origins.

Closely related is Rachlin's argument that "most of us would indeed choose to be heroes rather than cowards" (sect. 9, last para.). His explanation for the origin of this motivation is not clear. A fairly straightforward explanation arises from Campbell's (1975) suggestion that humans innately have both self-interested and social motivations, and Goldschmidt's (1990) impressively documented argument that the inclination to work for the respect of one's fellows is a central component of human nature. In fact, much prosocial behavior may well be traceable to the way in which cultures use respect as a reward for such behavior. This also provides a nice example of the way in which an innate inclination could provide the leverage for a great deal of learning. Far from being in conflict with an explanation based on learning, the evolutionarily based motivation would be what makes the learning possible. 
Rachlin is undoubtedly correct in his assertion that self-control is learned. However, his analysis would be strengthened by including the role of inhibition in managing our behavior. Inhibition is essential to self-control. Without the ability to inhibit the effect of the immediate environment, long-term goals cannot possibly affect present behavior. If people were unable to inhibit any stimuli, essentially forced to attend and respond to every next thing that the environment presented, then contemplation, recollection, and behavioral continuity, necessary for all of Rachlin's examples, would be unattainable.

Rachlin supposes that self-control is accomplished by an innate learning mechanism. Yet such a mechanism would be unable to inhibit immediate stimuli so as to allow a longer-term pattern to come into play. The mechanism of self-control involves more than just learning habits; there is also the need to direct one's attention. Directed attention (Kaplan 1995; Mesuluam 1985) is useful in dealing with just the sorts of short-term versus long-term behavioral choices that Rachlin sets up: inhibiting the power of the immediate environment so as to allow consideration of less salient but nonetheless valued patterns. Directed attention allows for a variety of prosocial behaviors (e.g., pursuit of an important social goal despite interesting competition in the immediate setting, helping others despite unmet personal needs, and resisting temptation to maintain devotion to a larger pattern).

A re-analysis of Rachlin's examples offers some insight on the role of inhibition. The example of a woman entering a burning building is ambiguous because many of the stimuli present (e.g., onlookers screaming that someone is trapped, a child's scream for help) are both involuntarily fascinating (James 1892) and conceivably capable of prompting a short-term pattern (e.g., entering the building) that is closely linked with the longer-term pattern of prosocial behavior. The behavior of a recovering alcoholic better demonstrates the enormous adaptive advantage offered by inhibition. Here the environmental stimuli conspire mightily against sobriety. Yet, the recovering alcoholic's self-control is only possible because of the ability to hold the immediate environment at bay and the insertion of cognition between stimulus and response.

The desire not to have to use self-control is a most interesting and useful contribution which fits well with the recent work showing that directed attention is a scarce and labile resource. When under continual demand, our ability to direct our inhibitory process tires, resulting in a condition called directed attention fatigue (DAF). This condition reduces mental effectiveness and makes consideration of abstract long-term goals difficult. A number of symptoms are commonly attributed to this fatigue: irritability and impulsivity that results in regrettable choices, impatience that has us making ill-formed decisions, and distractibility that allows the immediate environment to have a magnified affect on our behavioral choices. The symptoms of DAF can be summarized as a reduced ability to make and follow plans, and the inability to mentally restrain impulsive thought or action. In short, DAF makes prosocial behavior at any temporal scale less likely.

We would thus like to commend Rachlin for his fascinating treatment of the problem of long-term versus short-term interests, for his focus on self-control (and its limitations), and his linking all this to prosocial behavior. At the same time, we would encourage him to consider evolutionary perspectives less extreme than those he has apparently been reading, and to explore the possible role of directed attention as a useful tool in his further exploration of the self-control concept.

\section{Is the prisoner's dilemma metaphor suitable for altruism? Distinguishing self-control and commitment from altruism}

Elias L. Khalil

Behavioral Research Council, American Institute for Economic Research, Great Barrington, MA 01230. elk@aier.org http://www.brc-aier.org

Abstract: Rachlin basically marshals three reasons behind his unconventional claim that altruism is a subcategory of self-control and that, hence, the prisoner's dilemma is the appropriate metaphor of altruism. I do not find any of the three reasons convincing. Therefore, the prisoner's dilemma metaphor is unsuitable for explaining altruism.

Rachlin claims that altruism is a subcategory of self-control, known also as the precommitment or weakness-of-will problem (Elster 2000). I can surmise three separate reasons behind this unconventional claim.

1. For Rachlin, self-control and altruism share one element, namely, that a single action has no meaning. The action has to be part of a pattern, which may be reinforced, to provide the context. The context allows one to judge whether the action is self-control, as when an alcoholic prefers soft drink over scotch, and whether the action is altruism, as when we see a woman running into a building on fire and emerging with a child that is unrelated to her biologically. Rachlin calls his approach "teleological behaviorism" and relates it to Aristotle's concept of habit as motivated by final causes. He characterizes it as "complex ambivalence" to show the repetitiveness of the acts - in opposition to the work of Platt (1973) and Messick and McClelland (1983). Context matters: The alcoholic might have made his choice because his boss is watching; the woman might have gone back into the building to salvage her jewelry when she stumbled on the child.

I have three reasons to doubt the issue of pattern so emphasized by Rachlin. First, Rachlin himself in many places mentions that altruism is a single act that does not need to be reinforced - in the woman-running-into-burning-building example, it's possible she might not exit alive from the burning building. He states that "an altruistic act is defined as a choice of the $t$-length fraction of the longer activity over the brief activity under Conditions 1, 2, and 3" (target article, sect. 4). If so, it is a single act. Second, even if Rachlin consistently defines altruism as a pattern like self-control, why should the observation of a pattern of apparently series acts of altruism or series acts of self-control make us sure that what we are observing is altruism or self-control? It is possible that each time one observes the woman doing what appears to be an altruistic act, she has her own private reason; or each time one observes the alcoholic abstaining from scotch, he has his own reason. The consistency of the pattern does not make one more certain of the motive - the desire of the actor to please the observer might be the motive. So, if you are a behaviorist, the logical problem of deducing the motive behind a pattern of acts is no less problematic than deducing the motive in a single act. Therefore, why resort to the idea of a pattern, when you have to end up asking the person anyhow if she is an altruist or if he abstains from alcohol? To ask the agent is fraught with problems - which do not go away with the idea of a pattern. Third, even if the pattern idea is a crucial element for deciding on altruism and self-control, this hardly makes them similar enough to justify the use of the same prisoner's dilemma (PD) metaphor for both. Bats and birds both fly. This does not make the bat's forelimbs wings. The sharing of the pattern feature at best suggests a heterologous metaphor - not a unificational or even a homologous similarity to justify the use of the same conceptual machinery (Khalil 2000).

2. Although Rachlin emphasizes the pattern issue, it is not the only similarity he finds. He argues that the "particular components of an altruistic pattern, like those of a self-controlled pattern, are less valuable to the actor than are their immediate alternatives" (sect. 4). That is, the alcoholic finds that one instance of abstention from scotch is less valuable than its immediate alternative 
learn it is genetic; if you show that a certain behavioral trait is genetically determined I can always show that the expression of that trait depends on the environment. Whether the properties of a ripe red apple in my left hand are genetically or environmentally determined depends on what I am holding in my right hand. If it's an orange, then the apple's properties will seem genetic; if it's another apple in my right hand, say, a green, unripe one from the shady side of the tree, then the apple's properties will seem environmentally determined. To say that altruism may be learned is not to say that "there is no genetic variance in propensity toward altruism" (Hartung, Zizzo), or "to eliminate the potential role of evolution" (Kaplan \& De Young), or to be "averse to considering the genetic basis of behavior" (Zentall), any more than the fact that calculus may be learned means that there is no genetic variance in the ability to learn calculus or that the role of evolution in our ability to learn calculus has been eliminated. The fact that, in free choice tests, a hungry rat spends more time in eating than in wheelrunning, and more time in wheel-running than in leverpressing, has two kinds of implications: one, the behavioral implication that certain contingent relations among these three activities will be found (e.g., wheel-running will reinforce lever-pressing but punish eating); another, that some internal mechanism or mechanisms that are partly innate, partly themselves learned, underlie the behavior. To say that one implication is important does not deny that the other is also important.

Krebs seems to believe that I was trying to say something about how altruism evolved. But I did not even mean to say that self-control came before altruism in the course of human evolution; the reverse might well be true. A behavioristic theory would be silent on how altruism was selected. I did call the self-control mechanism an "innate learning mechanism" but Premack's (1969) reinforcement theory would not distinguish such a mechanism from an evolved strategy. All I intended to claim with respect to a common mechanism is that in both cases, self-control and altruism, evolution must select behavioral patterns rather than individual acts. Individual acts would be reinforced to the extent that they formed part of a valuable pattern. Whatever mechanism did this would be a "learning mechanism."

Wilson \& Miller accuse me of setting up a straw man in claiming that biologists posit a specialized altruism mechanism. Then they proceed to make virtually the same claim, only now it's a "specialized form of learning." I had presumed that when Tooby and Cosmides (1992) compared the supposed specialized mechanism to the eye they were minimizing the contribution of learning. If I was wrong, I apologize. If there were a specialized form of learning, as Wilson \& Miller claim, the question becomes, "What does that specialized mechanism do?" If, as I claim, it organizes low-valued particular acts into high-valued patterns, and if we had one such mechanism for self-control and one for altruism, then we would have two mechanisms doing the very same thing. It seems to me that in the absence of physiological evidence for two such redundant mechanisms we ought to assume that only one exists.

\section{R6. Morality}

Being from the Bronx, I certainly do not belong among Hartung's five known pure altruists. That leaves only four remaining. Still, we should try to explain their behavior because, on a lower level, altruism is a pattern in all of our lives. The players of the prisoner's dilemma game illustrated in Figure 1 who anonymously chose $\mathrm{Y}$ are good examples. When I was a Boy Scout I occasionally helped old ladies across the street (I still do, although now I'm less disinterested). I did not do so in fear of hell or hope of heaven, as Hartung and Levine would seem to require. Despite the rhetoric, fear of hell and hope of heaven are not by themselves good explanations of altruistic behavior. We still would need to explain, in behavioral terms, how such fears and hopes work. As I said in the target article, there is a distinction to be made between altruism and morality. The behavior of the firemen and the hijackers on September $11^{\text {th }}$ may have been equally altruistic but not, from our viewpoint, equally moral. Wagstaff cites cases where altruistic acts turn out to be socially harmful: "The man who impulsively sacrifices himself to help anyone, including gangsters and tyrants, may be acting selflessly, but he is also a social liability." Correct. This was the point of my example in the target article of the Nazi soldier sacrificing himself for his unit. Wagstaff makes the point, implicit in Lacey's commentary, that no account of altruism is complete without an understanding of justice. Such an understanding would enable us to distinguish more clearly between altruism and morality. I agree.

\section{References}

[Note: The letters " $a$ " and " $r$ " before author's initials stand for target article and response references, respectively.]

Abelson, R. P., Frey, K. P. \& Gregg, A. P. (in press) Experiments with people: Revelations from social psychology. Erlbaum. [CS]

Ainslie, G. (1992) Picoeconomics. Cambridge University Press. [aHR, JS]

(1995) A utility-maximizing mechanism for vicarious reward. Rationality and Society 7:393-403. [GA]

(2001) Breakdown of will. Cambridge University Press. [GA, HM]

Ainslie, G. \& Monterosso, J. (in press) Building blocks of self-control: Increased tolerance for delay with bundled rewards. Journal of the Experimental Analysis of Behavior. [GA]

Alexander, R. D. (1987) The biology of moral systems. Aldine de Gruyter. [JS, CW, DJZ]

Apostle, H. G. (1984) Translator, Aristotle's Nicomachean ethics. The Peripatetic Press. [rHR]

Aristotle (1984) The complete works of Aristotle, ed. Barnes. Princeton University Press. [GFW]

Aron, A., Aron, E. N. \& Smollan, D. (1992) Inclusion of other in the self scale and the structure of interpersonal closeness. Journal of Personality and Social Psychology 63:596-612. [CS]

Aron, A., Aron, E. N., Tudor, M. \& Nelson, G. (1991) Close relationships as including other in the self. Journal of Personality and Social Psychology 60:241-53. [CS]

Axelrod, R. (1984) The evolution of cooperation. Basic Books. [AAS, CW, TRZ] (1997) The complexity of cooperation: Agent based models of competition and collaboration. Princeton University Press. [aHR]

Axelrod, R. \& Hamilton, W. D. (1981) The evolution of cooperation. Science 211:1390-96. [HG, TRZ]

Bacharach, M., Guerra, G. \& Zizzo, D. J. (2001) Is trust self-fulfilling? An experimental study. Department of Economics Discussion Paper No. 76 University of Oxford. http://www.economics.ox.ac.uk/Research/ working_papers.htm [[DJZ]

Baker, F. \& Rachlin, H. (2001) Probability of reciprocation in prisoner's dilemma games. Journal of Behavioral Decision Making 14:51-67. [ JIK, arHR]

(2002) Self-control by pigeons in the prisoner's dilemma. Psychonomic Bulletin and Review 9:482-88. [rHR]

(2002) Teaching and learning in a probabilistic prisoner's dilemma. Behavioral Processes. 57:211-26. [aHR]

Bandura, A. (1972) Modeling theory: Some traditions, trends, and disputes. In: 
Recent trends in social learning theory, ed. R. D. Parke. Academic Press. [RCG]

Bandura, A., Ross, D. \& Ross, S. A. (1963) Vicarious reinforcement and imitative learning. Journal of Abnormal and Social Psychology 67:601-607. [RCG]

Baron, J. (1997a) Politival action vs. voluntarism in social dilemmas and aid for the needy. Rationality and Society 9:307-26. [JB]

(1997b) The illusion of morality as self-interest: A reason to cooperate in social dilemmas. Psychological Science 8:330-35. [JB]

(2001) Confusion of group-interest and self-interest in parochial cooperation on behalf of a group. Journal of Conflict Resolution 45:283-96. [JB]

Batali, J. (1998) Computational simulations of the emergence of grammar. In: Approaches to the evolution of language: Social and cognitive bases, ed. J Hurford \& M. Studdert-Kennedy. Cambridge University Press. [WZ]

Batson, C. D. (1987) Prosocial motivation: Is it ever truly altruistic? In: Advances in experimental social psychology, vol. 20, ed. L. Berkowitz. Academic Press. [GFW]

(1990) How social an animal? The human capacity for caring. American Psychologist 45:336-46. [MP]

(1991) The altruism question: Toward a social-psychological answer. Erlbaum. [DSW]

(1998) Altruism and prosocial behavior. In: The handbook of social psychology, vol. 2, ed. D. T. Gilbert, S. T. Fiske \& G. Lindzey. McGraw-Hill. [GC]

Batson, C. D., Batson, J. G., Todd, M. R., Brummett, B. H., Shaw, L. L. \& Aldeguer, C. M. R. (1995) Empathy and the collective good: Caring for one of the others in a social dilemma. Journal of Personality and Social Psychology 68:619-31. [MP]

Batson, C. D. \& Oleson, K. C. (1991) Current status of the empathy-altruism hypothesis. In: Review of Personality and Social Psychology, vol. 12: Altruism, ed. M. Clark. Sage. [RB]

Batson, C. D., Sager, K., Garst, E., Kang, M., Rubchinsky, K. \& Dawson, K. (1997) Is empathy-induced helping due to self-other merging? Journal of Personality and Social Psychology 73:495-509. [CS]

Batson, C. D. \& Shaw, L. L. (1991) Evidence for altruism: Toward a pluralism of prosocial motives. Psychological Inquiry 2:159-68 or 2:107-22. [GA, RB]

Baum, W. M. (1994) Understanding behaviorism: Science, behavior, and culture. Harper Collins. [aHR]

Baum, W. M. \& Rachlin, H. (1969) Choice as time allocation. Journal of the Experimental Analysis of Behavior 12:861-74. [EJF]

Baumeister, R. F. (1999) The self in social psychology. Psychology Press. [RAH] (2000) Ego depletion and the self's executive function. In: Psychological perspectives on self and identity, ed. A. Tesser, R. B. Felson \& J. M. Suls. American Psychological Association. [rHR]

Baumeister, R. F. \& Leary, M. R. (1995) The need to belong: Desire for interpersonal attachments as a fundamental human motivation. Psychological Bulletin 117:497-529. [CS]

Bechara, A., Damasio, H., Tranel, D. \& Anderson, S. W. (1998) Dissociation of working memory from decision making within the human prefrontal cortex. Journal of Neuroscience 18:428-37. [ JRG]

Becker, G. S. (1981) Altruism in the family and selfishness in the market place. Economica 48:1-15. [EKL]

Beecher, M. D., Campbell, S. E. \& Nordby, J. C. (2000) Territory tenure in song sparrows is related to song sharing with neighbors, but not to repertoire size. Animal Behaviour 59:29-37. [RS]

Beggan, J. K. (1992) On the social nature of nonsocial perception: The mere ownership effect. Journal of Personality and Social Psychology 62:229-37. [CS]

Bergstrom, T. C. (1995) On the evolution of altruistic ethical rules for siblings. American Economic Review 85:58-81. [DJZ]

Berridge, K. C. (2000) Measuring hedonic impact in animals and infants: Microstructure of affective taste reactivity patterns. Neuroscience and Biobehavioral Reviews 24:173-98. [RS]

Bickel, W. K. \& Vuchinich, R. E. (2000) Reframing health behavior change with behavioral economics. Erlbaum. [aHR]

Bindra, D. (1959) Motivation: A systematic reinterpretation. Ronald Press. [RAH]

Boehm, C. (1997) Impact of the human egalitarian syndrome on Darwinian selection mechanics. The American Naturalist 34:S100-S121. [JS]

Boesch, C. \& Boesch, H. (1989) Hunting behavior of wild chimpanzees in the Tai National Park. American Journal of Physical Anthropology 78:547-73. [RS]

Boksa, P., Wilson, D. \& Rochford, J. (1998) Responses to stress and novelty in adult rats born vaginally, by caesarean section, or caesarean section with acute anoxia. Biology of the Neonate 74:48-59. [GC]

Bowlby, J. (1969) Attachment and loss, vol. 1: Attachment. Basic Books. [DSW]

Boyd, R. \& Richerson, P. J. (1985) Culture and the evolutionary process. University of Chicago Press. [HG]

Brann, P. \& Foddy, M. (1988) Trust and the consumption of a deteriorating common resource. Journal of Conflict Resolution 31:615-30. [aHR, RS]

Braver, T. S. \& Cohen, J. D. (2000) On the control of control: The role of dopamine in regulating prefrontal function and working memory. In: Control of processes: Attention and Performance XVIII, ed. S. Monsell \& J. Driver. MIT Press. [JRG]

Broude, G. J. (1995) Growing up. ABC-CLIO. [GJB]

Brown, J. (2000) Delay discounting if multiple reinforcers following a single choice. Unpublished doctoral dissertation, Psychology Department, State University of New York at Stony Brook. [aHR]

Brown, J. \& Rachlin, H. (1999) Self-control and social cooperation. Behavioral Processes 47:65-72 [aHR]

Buck, R. (1985) Prime theory: An integrated view of motivation and emotion. Psychological Review 92:389-413. [RB]

(1988) Human motivation and emotion, $2^{\text {nd }}$ edition. Wiley. [RB]

(1999) The biological affects: A typology. Psychological Review 106(2):729-38. [RB]

Campbell, D. T. (1975) Conflicts between biological and social evolution and between psychology and moral traditions. American Psychologist 30:1103126. [SK]

Caporael, L. R., Dawes, R. M., Orbel, J. M. \& van de Kragt, A. J. C. (1989) Selfishness examined: Cooperation in the absence of egoistic incentives. Behavioral and Brian Sciences 12:683-739. [aHR]

Carlo, G., Eisenberg, N., Troyer, D., Switzer, G. \& Speer, A. L. (1991) The altruistic personality: In what contexts is it apparent? Journal of Personality and Social Psychology 61:450-58. [MP]

Carlo, G. \& Randall, B. (2001) Are all prosocial behaviors equal? A socioecological developmental conception of prosocial behavior. In: Advances in psychology research, vol. II, ed. F. Columbus. Nova Science. [GC]

Caro, T. M. (1994) Cheetahs of the Serengeti Plains: Group living in an asocial species. University of Chicago Press. [RS]

Cavalli-Sforza, L. L. \& Feldman, M. W. (1981) Cultural transmission and evolution. Princeton University Press. [HG]

Chapman, G. B. (1998) Sooner or later: The psychology of intertemporal choice. In: The psychology of learning and motivation, vol. 38, ed. D. L. Medin. Academic Press. [RCG]

Charles, R. (1962) Them that got. In: Ray Charles Greatest Hits (record album; for lyrics, visit http://www.thepeaches.com/music/raycharles/ThemThatGot.txt). $[\mathrm{JH}]$

Charness, G. \& Rabin, M. (2000) Social preferences: Some simple tests and a new model. Department of Economics Working Paper No. 283, University of California at Berkeley. http://www.haas.berkeley.edu/groups/iber/wps/ econwp.html [DJZ]

Chartrand, T. L. \& Bargh, J. A. (1999) The chameleon effect: The perceptionbehavior link and social interaction. Journal of Personality and Social Psychology 76:893-910. [RS]

Chisholm, J. S. (1999) Death, hope and sex. Cambridge University Press. [DSW]

Cialdini, R. B., Brown, S. L., Lewis, B. P., Luce, C. \& Neuberg, S.L. (1997) Reinterpreting the empathy-altruism relationship: When one into one equals oneness. Journal of Personality and Social Psychology 73:481-94. [CS]

Cialdini, R. B., Daumann, D. J. \& Kendrick, D. T. (1981) Insights from sadness: A three step model of the development of altruism as hedonism. Developmental Review 1:207-23. [GFW]

Clements, K. C. \& Stephens, D. W. (1995) Testing models of non-kin cooperation: Mutualism and the Prisoner's Dilemma. Animal Behavior 50:527-35. [RS]

Colby, A. \& Damon, W. (1995) The development of extraordinary moral commitment. In: Morality in everyday life, ed. M. Killen \& D. Hart. Cambridge University Press. [RAH]

Cookson, R. (2000) Framing effects in public good experiments. Experimental Economics 3:55-79. [DJZ]

Cosmides, L. \& Tooby, J. (1992) Cognitive adaptations for social exchange. In: The adapted mind, ed. J. H. Barkow, L. Cosmides \& J. Tooby. Oxford University Press. [GJB]

Danielson, P. (2002) Competition among cooperators: Altruism and reciprocity. Proceedings of the National Academy of Sciences USA 99 (Suppl. 3):7237-42. [PD]

Darley, J. M. \& Batson, C. D. (1973) From Jerusalem to Jericho: A study of situational and dispositional variables in helping behavior. Journal of Personality and Social Psychology 27:100-108. [JIK]

Daumann, D. J., Cialdini, R. B. \& Kendrick, D. T. (1981) Altruism as hedonism: Helping and self-gratification as equivalent responses. Journal of Personality and Social Psychology 40:1039-46. [GFW]

Davis, M. H., Luce, C. \& Kraus, S. J. (1994) The heritability of characteristics associated with dispositional empathy. Journal of Personality 62:362-91. $[\mathrm{JH}]$

Dawes, R. (1980) Social dilemmas. Annual Review of Psychology 31:169-93. [aHR]

Dawkins, R. (1976/1989) The selfish gene. (2 ${ }^{\text {nd }}$ edition, 1989). Oxford University Press. [aHR, RS, GFW]

De Bruin, E. N. M. \& van Lange, P. A. M. (1999) Impression formation and cooperative behavior. European Journal of Social Psychology 29:305-28. [JIK] 
Deguchi, H. (1984) Observational learning from a radical-behavioristic viewpoint. The Behavior Analyst 7:83-95. [RCG]

Dellu, F., Mayo, W., Vallèe, M., Piazza, P. V., Le Moal, M. \& Simon, H. (1996) Behavioral reactivity to novelty during youth as a predictive factor of stressinduced corticosterone secretion in the elderly - a life-span study in rats. Psychoneuroendocrinology 21:441-53. [GC]

Dennett, D. C. (1984) Elbow room: The varieties of free will worth wanting. MIT Press. [aHR]

Derryberry, D. \& Rothbart, M. K. (1988) Arousal, affect, and attention as components of temperament. Journal of Personality and Social Psychology 55:958-66. [GC]

De Waal, F. B. M. \& Aureli, F. (1997) Conflict resolution and distress alleviation in monkeys and apes. In: Annals of the New York Academy of Sciences, vol. 807: The integrative neurobiology of affiliation, ed. C. S. Carter, I. I. Lederhendler \& B. Kirkpatrick. The New York Academy of Sciences. [RB]

Dovidio, J. F., Gaertner, S. L., Isen, A. M. \& Lowrance, R. (1995) Group representations and intergroup bias: Positive affect, similarity, and group size. Personality and Social Psychology Bulletin 21:856-65. [JRG]

Duckitt, J. (1992) The social psychology of prejudice. Praeger. [CS]

Dugatkin, L. A. (1997) Cooperation among animals: An evolutionary perspective. Oxford University Press. [RS]

Dunning, D. (1993) Words to live by: The self and definitions of social concepts and categories. In: Psychological perspectives on the self, vol. 4, ed. J. Suls. Erlbaum. [CS]

Dyson, F. (1970) Time without end: Physics and biology in an open universe. Reviews of Modern Physics 51:447-60. [ JH]

Edney, J. J. (1980) The commons problem: Alternative perspectives. American Psychologist 35:131-50. [aHR]

Eisenberg, N. \& Fabes, R. A. (1991) Prosocial behavior and empathy: A multimethod developmental perspective. In: Prosocial behavior, ed. M. S. Clark. Sage. [RB]

(1998) Prosocial development. In: Handbook of child psychology, vol. 3: Social, emotional, and personality development, $5^{\text {th }}$ edition, ed. N. Eisenberg. (Series ed. W. Damon). Wiley. [GC]

Eisenberg, N. \& Miller, P. (1987) The relation of empathy to prosocial and related behaviors. Psychological Bulletin 101:91-119. [RB]

Elster, J. (2000) Ulysses bound. Cambridge University Press. [ELK]

Falk, A. \& Fischbacher, U. (1998) A theory of reciprocity. IEW Working Paper No 6, University of Zurich. http://www.iew.unizh.ch/home/fischbacher [DJZ]

Fantino, E. \& Stolarz-Fantino, S. (2002) From patterns to prosperity: A review of Rachlin's The science of self-control. Journal of the Experimental Analysis of Behavior 78:117-25. [EJF]

Fehr, E. \& Gächter, S. (2000) Fairness and retaliation: The economics of reciprocity. Journal of Economic Perspectives 14:159-81. [ELK]

Fehr, E. \& Schmidt, K. (1999) A theory of fairness, competition, and cooperation. Quarterly Journal of Economics 114:817-68. [DJZ]

(2002) Altruistic punishment in humans. Nature 415:137-40. [HG, CW]

Field, A. (2001) Altruistically inclined? The behavioral sciences evolutionary theory and the origins of reciprocity. University of Michigan Press. [GA]

Fiske, A. P. (1991) The cultural relativity of selfish individualism: Anthropological evidence that humans are inherently sociable. In: Review of Personality and Social Psychology, vol. 12: Altruism and social behavior, ed. M. Clark. Sage. [GA]

Foddy, M., Smithson, M., Schneider, S. \& Hogg, M. A., eds. (1999) Resolving social dilemmas: Dynamics, structural, and intergroup aspects. Psychology Press. [AAS]

Foddy, M. \& Veronese, D. (1996) Does knowing the jointly rational solution make you want to pursue it? In: Frontiers in social dilemmas research, ed. W. B. G. Liebrand \& D. M. Messick. Springer. [AAS]

Forsythe, R., Horowitz, J., Savin, N. \& Sefton, M. (1994) Replicability, fairness and play in experiments with simple bargaining games. Games and Economic Behavior 6:347-69. [RS]

Frank, R. H. (1988) Passions within reason: The strategic role of the emotions. W. W. Norton. [RS]

Frank, R. H., Gilovich, T. \& Regan, D. (1993) Does studying economics inhibit cooperation? Journal of Economic Perspectives 7:159-71. [GA]

Frautschi, S. (1987) Entropy in an expanding universe. Science 217:593-99. [JH]

Fry, P. S. (1977) Success, failure, and resistance to temptation. Developmental Psychology 13:519-20. [JRG]

Fudenberg, D. \& Maskin, E. (1990) Evolution and cooperation in noisy repeated games. New Developments in Economic Theory 80:274-79. [aHR]

Gallucci, M. \& Perugini, M. (2000) An experimental test of a game-theoretical model of reciprocity. Journal of Behavioral Decision Making 13:367-89. [MP]

Gauthier, D. (1986) Morals by agreement. Oxford University Press. [PD]

Gilligan, C. \& Attanucci, J. (1988) Two moral orientations: Gender differences and similarities. Merrill-Palmer Quarterly 34(3):223-37. [RB]
Gintis, H., Smith, E. A. \& Boules, S. (2001) Costly signalling and cooperation. Journal of Theoretical Biology 213:103-19. [DR, CW]

Goldschmidt, W. (1990) The human career: The self in the symbolic world. Blackwell. [SK]

Gray, J. R. (1999) A bias toward short-term thinking in threat-related negative emotional states. Personality and Social Psychology Bulletin 25:65-75. [JRG]

(2001) Emotional modulation of cognitive control: Approach-withdrawal states double-dissociate spatial from verbal two-back task performance. Journal of Experimental Psychology: General 130:436-52. [JRG]

Gray, J. R., Braver, T. S. \& Raichle, M. E. (2001) Integration of emotion and cognition in lateral prefrontal cortex. Proceedings of the National Academy of Sciences USA 99:4115-20. [JRG]

Green, L., Price, P. C. \& Hamburger, M. E. (1995) Prisoner's dilemma and the pigeon: Control by immediate consequences. Journal of the Experimental Analysis of Behavior 64:1-17. [RS]

Green, L. \& Rachlin, H. (1996) Commitment using punishment. Journal of the Experimental Analysis of Behavior 65:593-601. [aHR]

Grim, P. (1995) Greater generosity of the spatialized prisoner's dilemma. Journal of Theoretical Biology 173:353-59. [PG]

1996) Spatialization and greater generosity in the stochastic prisoner's dilemma. BioSystems 37:3-17. [PG]

Grim, P., St. Denis, P. \& Kokalis, T. (2002) Learning to communicate: The emergence of signaling in spatialized arrays of neural nets. Adaptive Behavior. (forthcoming). [PG]

Gul, F. \& Pesendorfer, W. (2001) Temptation and self-control. Econometrica 69:1403-35. [JS]

Gurven, M., Allen-Arave, W., Hill, K. \& Hurtado, M. (2000) "It's a wonderful life": Signaling generosity among the Ache of Paraguay. Evolution and Human Behavior 21:263-82. [DR]

Guth, W., Marchand, N. \& Rullière, J.-L. (1998) Equilibration et dépendance du context: Une évaluation expérimentale du jeu de négociation sous ultimatum. Revue Economique 49:785-94. [DJZ]

Hake, D. F. \& Vukelich, R. (1972) A classification and review of cooperation procedures. Journal of the Experimental Analysis of Behavior 18:333-43. [RS]

Hamilton, W. D. (1964) The evolution of social behavior. Journal of Theoretical Biology $7: 1-52 . \quad[\mathrm{DR}, \mathrm{JS}]$

Hardin, G. (1968) The tragedy of the commons. Science 162:1243-48. [CW]

Harlow, H. F. (1953) Mice, monkeys, men and motives. Psychological Review 60:23-32. [SK]

Harper, L. (1989) The nurture of human behavior. Ablex. [GJB]

Harter, S. (1998) The development of self-representations. In: Handbook of child psychology: Social, emotional and personality development, vol. 3, ed. W. Damon \& N. Eisenberg. Wiley. [RAH]

Hartung, J. (1995) Love thy neighbor: The evolution of in-group morality. Skeptic 3(4):86-98. [ JH]

(1996) Prospects for existence: Morality and genetic engineering. Skeptic $4(2): 62-71 . \quad[\mathrm{JH}]$

(2001) The message of evolution. http://members.aol.com/_ht_a/toexist/ Message.html [JH]

Hauert, C. \& Schuster, H. G. (1997) Effects of increasing the number of players and memory size in the iterated Prisoner's Dilemma: A numerical approach. Proceedings of the Royal Society of London B 264:513-19. [CW]

Hawkes, K., O’Connell, J. F. \& Blurton Jones, N. G. (2001) Hadza meat sharing. Evolution and Human Behavior 22:113-42. [RAH]

Hayes, S. C. (1989) Rule-governed behavior: Cognition, contingencies, and instructional control. Plenum Press. [aHR]

Herrnstein, R. J. (1991) Experiments on stable suboptimality in individual behavior. American Economic Review 81:360-64. [HM, aHR]

Herrnstein, R. J. \& Prelec, D. (1992) A theory of addiction. In: Choice over time, ed. G. Loewenstein \& Elster. Russell Sage Foundation. [aHR]

Herrnstein, R. J., Prelec, D. \& Vaughan, W, Jr. (1986) An intra-personal prisoners dilemma. Paper presented at the IX Symposium on Quantitative Analysis of Behavior: Behavioral Economics, Harvard University. [aHR]

Heyman, G. M. (1996) Resolving the contradictions of addiction. Behavioral and Brain Sciences 19:561-610. [aHR]

Hinde, R. A. (2002) Why good is good. Routledge. [RAH]

Hoffman, M. L. (1975) Developmental synthesis of affect and cognition and its implications for altruistic motivation. Developmental Psychology 11:607-22. [RB]

(1976) Empathy, role-taking, guilt, and development of altruistic motives. In: Moral development and behavior: Theory, research, and social issues, ed. T. Lickona. Holt, Rinehart and Winston. [RB]

(1991) Empathy, social cognition, and moral action. In: Handbook of moral behavior and development, vol. 1: Theory, ed. W. M. Kurtines \& J. L. Gewirtz. Erlbaum. [GC]

Hoyle, F., Burbridge, G. \& Narlikar, J. (2000) A different approach to cosmology: 
From a static universe through the big bang towards reality. Cambridge University Press. [ $\mathrm{JH}]$

Hurford, J. R. (2002) Expression/induction models of language. In: Linguistic evolution through language acquisition: Formal and computational models, ed. T. Briscoe. Cambridge University Press. [WZ]

Irwin, F. W. (1971) Intentional behavior and motivation: A cognitive theory. Lippincott. [JB]

Isen, A. M. (1972) Effects of feeling good on helping others: Cookies and kindness. Journal of Personality and Social Psychology 21:382-88. [JRG]

James, W. (1892) Psychology: The briefer course. Holt. [SK]

Kahneman, D., Knetsch, J. L. \& Thaler, R. H. (1990) Experimental test of the endowment effect and the coase theorem. Journal of Political Economy 98:1325-47. [CS]

Kaplan, S. (1995) The restorative benefits of nature: Toward an integrative framework. Journal of Experimental Psychology 15:169-82. [SK]

Kehoe, P., Shoemaker, W. J., Triano, L., Callahan, M. \& Rappolt, G. (1998) Adult rats stressed as neonates show exaggerated behavioral responses to both pharmacological and environmental challenges. Behavioral Neuroscience 112:116-25. [GC]

Kelley, H. H. \& Thibaut, J. W. (1978) Interpersonal relations: A theory of interdependence. Wiley. [MP]

Khalil, E. L. (1999) Sentimental fools: A critique of Amartya Sen's notion of commitment. Journal of Economic Behavior and Organization 40:373-86. [ELK]

(2000) Types of metaphor and identificational slips in economic discourse. Research in the History of Economic Thought and Methodology 18A:83-105. [ELK $]$

(2001) Adam Smith and three theories of altruism. Recherches Économiques de Louvain (Louvain Economic Review) 67:421-35. [rHR]

(2002) What is altruism? Journal of Economic Psychology 23. (in press). [ELK (in press) Why does trustworthiness pay? Three explanations: An introduction. In: Trust, ed. E. L. Khalil. Edward Elgar. [ELK]

Kirby, K. N. (1997) Bidding on the future: Evidence against normative discounting of delayed rewards. Journal of Experimental Psychology: General 126:54-70. [GA, RCG]

Kirby, K. N. \& Guastello, B. (2001) Making choices in anticipation of similar future choices can increase self-control. Journal of Experimental Psychology: Applied 7:154-64. [GA]

Kirby, S. (2000) Syntax without natural selection: How compositionality emerges from vocabulary in a population of learners. In: The evolutionary emergence of language: Social function and the origins of linguistic form, ed. C. Knight, J. Hurford \& M. Studdert-Kennedy. Cambridge University Press. http://ling.ed.ac.uk/anonftp/pub/staff/kirby/evo198.ps.gz [WZ]

Kitayama, S. \& Karasawa, M. (1997) Implicit self-esteem in Japan: Name letters and birthday numbers. Personality and Social Psychology Bulletin 23:736-42. [CS]

Komorito, S. S., Chan, D. K.-S. \& Parks, C. D. (1993) The effects of reward structure and reciprocity in social dilemmas. Journal of Experimental Social Psychology 29:252-67. [aHR]

Komorito, S. S. \& Parks, C. D. (1994) Social dilemmas. Brown and Benchmark. [aHR]

Konow, J. (2000) Fair shares: Accountability and cognitive dissonance in allocation decisions. American Economic Review 90:1072-91. [DJZ]

Krebs, J. R. (1982) Territorial defense in the great tit (Parus major): Do residents always win? Behavioral Ecology and Sociobiology 11:185-94. [RS]

Krebs, J. R. \& Davies, N. B. (1993) An introduction to behavioural ecology, third edition. Blackwell. [RS]

Kreps, D. M., Milgrom, P., Roberts, J. \& Wilson, R. (1982) Rational cooperation in the finitely repeated Prisoners' Dilemma. Journal of Economic Theory 27:245-52. [DJZ]

Krueger, J. (1998) On the perception of social consensus. Advances in Experimental Social Psychology 30:163-240. [JIK]

Kudadjie-Gyamfi, E. (1998) Patterns of behavior: Self-control choices among risky alternatives. Unpublished doctoral dissertation, Psychology Department, State University of New York at Stony Brook. [aHR]

Kudadjie-Gyamfi, E. \& Rachlin, H. (1996) Temporal patterning in choice among delayed outcomes. Organizational Behavior and Human Decision Processes 65:61-67 [aHR]

Lacey, H. (1995a) Teleological behaviorism and the intentional scheme. Behavioral and Brain Sciences 18:134-35. [HL]

(1995b) Behaviorisms: Theoretical and teleological. Review of John Staddon's Behaviorism: Mind, mechanism and society and Howard Rachlin's Behavior and mind: The roots of modern psychology. Behavior and Philosophy 23:6178. [HL]

Lacey, H. \& Schwartz, B. (1996) The formation and transformation of values. In: The philosophy of psychology, ed. W. O’Donohue \& R. F. Kitchener. Sage. [HL]

Larrick, R. P. \& Blount, S. (1997) The claiming effect: Why players are more generous in social dilemmas than in ultimatum games. Journal of Personality and Social Psychology 72:810-25. [MP]

Lawler, E. J., Thye, S. R. \& Yoon, J. (2000) Emotion and group cohesion in productive exchange. American Journal of Sociology 106:616-57. [ JRG]

Leary, M. R. \& Baumeister, R. F. (2000) The nature and function of self-esteem: Sociomotor theory. In: Advances in experimental social psychology, vol. 32, ed. M. P. Zanna. Academic Press. [CS]

Levine, D. K. (1998) Modeling altruism and spitefulness in experiments. Review of Economic Dynamics 1:593-622. [PD]

Lewin, K. (1936) Principles of topological psychology. McGraw-Hill. [aHR]

Lewis, M. (1979) The self as a developmental concept. Human Development 22:416-19. [ML]

(1992) Shame: The exposed self. The Free Press. [ML]

(1995) Self-conscious emotions. American Scientist 83:68-78. [ML]

Lichbach, M. I. (1996) The cooperator's dilemma. University of Michigan Press. [AAS]

Liu, D., Diorio, J., Tannanbaum, B., Caldji, C., Francis, D., Freedman, A., Sharma, S., Pearson, D., Plotsky, P. M. \& Meaney, M. J. (1997) Maternal care, hippocampal glucocorticoid receptors, and hypothalamic-pituitary-adrenal responses to stress. Science 277:1659-62. [GC]

Logue, A. W. (1988) Research on self-control: An integrating framework. Behavioral and Brain Sciences 11:665-709. [RS]

Logue, A. W., King, G. R., Chavarro, A. \& Volpe, J. S. (1990) Matching and maximizing in a self-control paradigm using human subjects. Learning and Motivation 21:340-68. [RS]

Lowenstein, G. F., Weber, E. U., Hsee, C. K. \& Welch, N. (2001) Risk as feelings. Psychological Bulletin 127:267-86. [RB]

Lumsden, C. J. \& Wilson, E. O. (1981) Genes, mind, and culture: The coevolutionary process. Harvard University Press. [HG]

MacCorquodale, K. \& Meehl, P. E. (1954) Edward C. Tolman. In: Modern learning theory, ed. W. K. Estes, S. Koch \& et al. Appleton-Century-Crofts. [RAH]

MacKay, D. M. (1965) Man as mechanism. In: The open mind and other essays, ed. D. M. MacKay \& M. Tinker. Inter-Varsity Press. [SK]

Margolis, H. (1982) Selfishness, altruism and rationality. Cambridge University Press. (Paper reprint 1984, University of Chicago Press). [HM] (2000) Self-interest and social motivation (Working Paper). http://www.harrisschool.uchicago.edu/wp/00-5.html [HM]

Marinoff, L. (1998) The failure of success: Intrafamilial exploitation in the prisoner's dilemma. In: Modeling rationality, morality, and evolution, vol. 7 , ed. P. Danielson. Oxford University Press. [PD]

Maynard Smith, J. (1978) The evolution of sex. Cambridge University Press. [RS] (1982) Evolution and the theory of games. Cambridge University Press. [WZ]

Mazur, J. E. (1987) An adjusting procedure for studying delayed reinforcement. In: Quantitative analysis of behavior, 5: The effects of delay and of intervening events on reinforcement value, ed. M. L. Commons, J. E. Mazur, J. A. Nevin $\&$ H. Rachlin. Erlbaum. [aHR]

McClennen, E. (1998) Rationality and rules. In: Modeling rationality, morality, and evolution, vol. 7, ed. P. Danielson. Oxford University Press. [PD, PW]

McClintock, C. G. (1972) Social motivation: A set of propositions. Behavioral Science 17:438-54. [AAS]

McGuire, W. J. \& McGuire, C. V. (1988) Content and process in the experience of self. Advances in Experimental Social Psychology 21:97-144. [RAH]

Medawar, P. B. \& Medawar, J. S. (1983) Aristotle to Zoos: A philosophical dictionary of biology. Harvard University Press. [DR]

Meltzoff, A. N. \& Moore, M. K. (1977) Imitation of facial and manual gestures by human neonates. Science 198:75-78. [RS]

Messick, D. M. \& McClelland, C. L. (1983) Social traps and temporal traps. Personality and Social Psychology Bulletin 9:105-10. [ELK, aHR]

Mesuluam, M. (1985) Principles of behavioral neurology. F. A. Davis. [SK]

Midgley, M. (1978) Beast and man. Cornell University Press. [GJB]

Milinski, M., Semmann, D., Bakker, T. C. M. \& Krambeck, H.-J. (2001) Cooperation through indirect reciprocity: Image scoring or standing strategy Proceedings of the Royal Society of London B 268:2495-501. [CW]

Milinski, M., Semmann, D. \& Krambeck, H.-J. (2002) Reputation helps solve the "tragedy of the commons." Nature 415:424-26. [CW]

Milinski, M. \& Wedekind, C. (1998) Working memory constrains human cooperation in the Prisoner's Dilemma. Proceedings of the National Academy of Sciences USA 95:13755-58. [CW]

Monterosso, J., Ainslie, G., Toppi-Mullen, P. \& Gault, B. (2002) The fragility of cooperation: A false feedback study of a sequential iterated prisoner's dilemma. Journal of Economic Psychology 23:437-48. [GA]

Nagel, T. (1970) The possibility of altruism. Clarendon Press. [PD]

Nesse, R. (2001) The evolution of subjective commitment. In: Evolution and the capacity for commitment, ed. R. Nesse. Russell Sage. [JS]

Neuberg, S. L., Cialdini, R. B., Brown, S. L., Luce, C. \& Sagarin, B. J. (1997) Does empathy lead to anything more than superficial helping? Comment on Batson et al. 1997. Journal of Personality and Social Psychology 73:510-16. [CS] 
Nowak, M. A., May, R. M. \& Sigmund, K. (1995) The arithmetics of mutual help. Scientific American 272:76-81. [CW]

Nowak, M. A., Page, K. M. \& Sigmund, K. (2000) Fairness versus reason in the Ultimatum Game. Science 289:1773-75. [CW]

Nowak, M. A. \& Sigmund, K. (1992) Tit-for-tat in heterogeneous populations. Nature 355:250-53. [CW]

(1993) A strategy of Win-Stay-Lose-Shift that outperforms Tit-for-Tat in the Prisoner's Dilemma game. Nature 364:56-58. [aHR, CW]

(1998a) The dynamics of indirect reciprocity. Journal of Theoretical Biology 194:561-74. [CW]

(1998b) Evolution of indirect reciprocity by image scoring. Nature 393:573-77. $[\mathrm{CW}]$

Nozick, R. (1993) The nature of rationality. Princeton University Press. [PW]

Nuttin, J. M. (1987) Affective consequences of mere ownership: The name letter effect in twelve European languages. European Journal of Social Psychology 17:381-402. [CS]

Ochsner, K. N. \& Lieberman, M. D. (2001) The emergence of social cognitive neuroscience. American Psychologist 56:717-34. [JRG]

Ostrom, E. (1998) A behavioral approach to the rational choice theory of collective action. American Political Science Review 92:1-22. [AAS]

Packer, C., Scheel, D. \& Pusey, A. E. (1990) Why lions form groups: Food is not enough. American Naturalist 136:1-19. [RS]

Paine, T. (1776) The American crisis. Pamphlet No. 1. Thomas Paine. [JH]

Palameta, B. \& Brown, W. M. (1999) Human cooperation is more than by-product mutualism. Animal Behaviour 57:F1-F3. [RS]

Palfrey, T. R. \& Prisbrey, J. E. (1997) Anomalous behavior in public goods experiments: How much and why? American Economic Review 87:829-46. [DJZ]

Panksepp, J. (1998) Affective neuroscience: The foundations of human and animal emotions. Oxford University Press. [GC]

Panksepp, J., Nelson, E. \& Bekkedal, M. (1997) Brain systems for the mediation of social separation-distress and social-reward. In: The integrative neurobiology of affiliation, ed. C. S. Carter, I. Lederhendler \& B. Kirkpatrick. New York Academy of Sciences. [RS]

Partif, D. (1971) Personal identity. Philosophical Review 80:3-27. [aHR]

Perugini, M. \& Gallucci, M. (2001) Individual differences and social norms: The distinction between reciprocators and prosocials. European Journal of Personality 15:S19-S35. [MP]

Phillips, S. T. \& Ziller, R. C. (1997) Toward a theory and measure of the nature of prejudice. Journal of Personality and Social Psychology 72:420-34. [CS]

Piliavin, J. A. \& Callero, P. L. (1991) Giving blood: The development of an altruistic identity. Johns Hopkins University Press. [AAS]

Pinker, S. \& Bloom, P. (1990) Natural language and natural selection. Behavioral and Brain Sciences 13:707-84. [WZ]

Platow, M. J. (1993) Observing social value orientations: A social interdependence approach. New Zealand Journal of Psychology 22:101-109. [AAS]

Platow, M. J., Durante, M., Williams, N., Garrett, M., Walshe, J., Cincotta, S., Lianos, G. \& Barutchu, A. (1999) The contribution of sport fan social identity to the production of prosocial behavior. Group Dynamics: Theory, Research and Practice 3:161-69. [AAS]

Platt, J. (1973) Social traps. American Psychologist 28:641-51. [ELK, aHR]

Posch, M. (1999) Win-stay, lose-shift strategies for repeated games - memory length, aspiration levels and noise. Journal of Theoretical Biology 198:183-95. $[\mathrm{CW}]$

Poulos, C. X., Parker, J. L. \& Lê, D. A. (1998) Increased impulsivity after injected alcohol predicts later alcohol consumption in rats: Evidence for "loss-ofcontrol drinking" and marked individual differences. Behavioral Neuroscience 112:1247-57. [GC]

Premack, D. (1965) Reinforcement theory. In: Nebraska Symposium on Motivation, ed. D. Levine. University of Nebraska Press. [aHR]

(1971) Catching up with common sense or two sides of generalization: Reinforcement and punishment. In: The nature of reinforcement, ed. R. Glaser. Academic Press. [rHR]

Preston, S. D. \& de Waal, F. B. M. (2002) Empathy: Its ultimate and proximate bases. Behavioral and Brain Sciences 25(1):1-70. [GA, RB]

Prins, K. S., Buunk, B. P. \& van Yperen, N. W. (1993) Equity, normative disapproval and extra martial relationships. Journal of Social and Personal Relationships 10:39-53. [RAH]

Quartz, S. R. \& Sejnowksi, T. J. (1997) The neural basis of cognitive development: A constructivist manifesto. Behavioral and Brain Sciences 20:537-96. [DJZ]

Quattrone, G. A. \& Tversky, A. (1984) Causal versus diagnostic contingencies: On self-deception and the voter's illusion. Journal of Personality and Social Psychology 46:237-48. [ JB, JIK]

Rachlin, H. (1994) Behavior and mind: The roots of modern psychology. Oxford University Press. [HL, aHR]

(1995a) Self-control: Beyond commitment. Behavioral and Brain Sciences 18:109-59. [HL, aHR, DR] (1995b) The value of temporal patterns in behavior. Current Directions in Psychological Science 4:188-91. [arHR]

(1997) Four teleological theories of addiction. Psychonomic Bulletin and Review 4:462-73. [arHR]

(2000) The science of self-control. Harvard University Press. [EJF, aHR]

Rachlin, H., Battalio, R., Kagel, J. \& Green, L. (1981) Maximization theory in behavioral psychology. Behavioral and Brian Sciences 4:371-417. [aHR]

Rachlin, H. \& Green, L. (1972) Commitment, choice and self-control. Journal of the Experimental Analysis of Behavior 17:15-22. [EJF]

Rapoport, A. \& Chammah, A. M. (1965) Prisoner's dilemma. University of Michigan Press. [aHR]

Rawls, J. (1971) A theory of justice. Harvard University Press. [PW]

Read, D. (2001) Intrapersonal dilemmas. Human Relations 54:1093-117. [DR]

Read, D., Loewenstein, G. \& Rabin, M. (1999) Choice bracketing. Journal of Risk and Uncertainty 23:5-32. [DR]

Reis, H. T. \& Judd, C. M. (2000) Handbook of research methods in social and personality psychology. Cambridge University Press. [CS]

Rescorla, R. A. \& Solomon, R. L. (1967) Two-process learning theory: Relations between Pavlovian conditioning and instrumental learning. Psychological Review 74:151-82. [rHR]

Rheingold, H. \& Hay, D. (1980) Prosocial behavior of the very young. In: Morality as a biological phenomenon, ed. G. S. Stent. University of California Press. [RAH]

Robins, L. N. (1974) The Vietnam drug user returns. Special Action Office Monograph, Series A, No. 2, United States Government Printing Office. [aHR]

Roelofsma, P. H. M. P. \& Read, D. (2000) Intransitive intertemporal choice. Journal of Behavioral Decision Making 13:161-77. [DR]

Rothbart, M. K., Ahadi, S. A. \& Hershey, K. L. (1994) Temperament and social behavior in childhood. Merrill-Palmer Quarterly 40:21-39. [GC]

Rushton, J. P., Eysenck, H. J., Fulker, D. W., Neale, M. C. \& Nias, D. K. B. (1986) Altruism and aggression: The heritability of individual differences. Journal of Personality and Social Psychology 50:1192-98. [JH]

Rushton, J. P., Fulker, D. W., Neale, M. C., Nias, D. K. B. \& Eysenck, H. J. (1986) Altruism and aggression: The heritability of individual differences. Journal of Personality and Social Psychology 50:1192-98. [DJZ]

Ryle, G. (1949) The concept of mind. Hutchinson House/Barnes and Noble. $[\mathrm{RB}, \mathrm{rHR}]$

Sabini, J. (1995) Social psychology. W. W. Norton. [GFW]

Scheel, D. \& Packer, C. (1991) Group hunting behaviour of lions: A search for cooperation. Animal Behaviour 41:697-709. [RS]

Schelling, T. (1971) The ecology of micromotives. Public Interest 25:61-98. [aHR]

(1984) Choice and consequence. Harvard University Press. [JS]

Schuster, R. (2001) An animal model of cooperating dyads: Methodological and theoretical issues. Revista mexicana de análysis de la conducta (Mexican Journal of Behavior Analysis) 27:165-200. [RS]

(in press) Cooperative coordination as a social behavior: Experiments with an animal model. Human Nature. [RS]

Schuster, R., Berger, B. D. \& Swanson, H. H. (1993) Cooperative social coordination and aggression: II. Effects of sex and housing among three strains of intact laboratory rats differing in aggressiveness. Quarterly Journal of Experimental Psychology 46B:367-90.[RS]

Schuster, R., Rachlin, H., Rom, M. \& Berger, B. D. (1982) An animal model of dyadic social interaction: Influence of isolation, competition and shockinduced aggression. Aggressive Behavior 8:116-21. [RS]

Sedikides, C. (1993) Assessment, enhancement, and verification determinants of the self-evaluation process. Journal of Personality and Social Psychology 65:317-38. [CS]

Sedikides, C. \& Green, J. D. (2000) On the self-protective nature of inconsistency/ negativity management: Using the person memory paradigm to examine selfreferent memory. Journal of Personality and Social Psychology 79:906-22. [CS]

Sedikides, C. \& Gregg, A. P. (in press) Self matters. In: Sage handbook of social psychology, ed. M. A. Hogg \& J. Cooper. Sage. [CS]

Sedikides, C. \& Skowronski, J. J. (1991) The law of cognitive structure activation. Psychological Inquiry 2:169-84. [CS]

Sedikides, C. \& Strube, M. J. (1997) Self-evaluation: To thine own self be good, to thine own self be sure, to thine own self be true, and to thine own self be better. In: Advances in experimental social psychology 29, ed. M. P. Zanna. Academic Press. [CS]

Seinen, I. \& Schramm, A. (2001) Social status and group norms: Indirect reciprocity in a helping experiment. Discussion Paper TI2001-003/1. Tinbergen Institute, Amsterdam. [CW]

Sethi, R. \& Somanathan, E. (2001) Preference evolution and reciprocity. Journal of Economic Theory 97:273-97. [PD]

Shafir, E. \& Tversky, A. (1992) Thinking through uncertainty: Nonconsequential reasoning and choice. Cognitive Psychology 24:449-74. [JB, JIK] 


\section{References/Rachlin: Altruism and selfishness}

Shaw, L. L., Batson, C. D. \& Todd, R. M. (1994) Empathy avoidance: Forestalling feeling for another to escape the motivational consequences. Journal of Personality and Social Psychology 67:879-87. [GA]

Sidgwick, H. (1893) Methods of ethics, $5^{\text {th }}$ edition. Macmillan. [PD]

Sidman, M. (1997) Equivalence relations. Journal of the Experimental Analysis of Behavior 68:258-66. [aHR]

Siegel, E. \& Rachlin, H. (1996) Soft commitment: Self-control achieved by response persistence. Journal of the Experimental of the Experimental Analysis of Behavior 64:117-28. [aHR]

Sigmund, K., Hauert, C. \& Nowak, M. A. (2001) Reward and punishment Proceedings of the National Academy of Sciences USA 98:10757-62. [CW]

Silverstein, A., Cross, D., Brown, J. \& Rachlin, H. (1998) Prior experience and patterning in a prisoner's dilemma game. Journal of Behavioral Decision Making 11:123-38. [aHR]

Simon, H. A. (1993) Altruism and economics. American Economic Review 83(2):156-61. [HG]

Skinner, B. F. (1938) The behavior of organisms: An experimental analysis Appleton-Century-Crofts. [aHR]

(1953) Science and human behavior. Macmillan. [RS]

Smith, E. R. \& Henry, S. (1996) An in-group becomes part of the self: Response time evidence. Personality and Social Psychology Bulletin 22:635-42. [CS]

Smuts, B. (1999) Multilevel selection, cooperation, and altruism. Human Nature 10(3):311-27. [ JS]

Snyder, M., Clary, E. G. \& Stukas, A. A. (2000) The functional approach to volunteerism. In: Why we evaluate: Functions of attitudes, ed. G. R. Maio \& J. M. Olson. Erlbaum. [AAS]

Sobel, J. (2001) Interdependent preferences and reciprocity. [JS]

Sober, E. \& Wilson, D. S. (1998) Unto others: The evolution and psychology of unselfish behavior. Harvard University Press. [HG, aHR, RS, JS, DSW]

Steels, L. (1999) The puzzle of language evolution. Kognitionswissenschaft 8(4):143-50. http:www.csl.sony.fr/downloads/papers/1999/steelskogwis1999.pdf [WZ]

Stipek, D., Recchia, S. \& McClintic, S. (1992) Self-evaluation in young children. Monograph of the Society for Research in Child Development 57 (1, Serial No. 226). [ML]

Stout, R. (1996) Things that happen because they should. Oxford University Press. [aHR

Tobin, H., Logue, A. W., Chelonis, J. J., Ackerman, K. T. \& May, J. G., III. (1996) Self-control in the monkey (Macaca fasicularis). Animal Learning and Behavior 24:168-74. [RS]

Tooby, J. \& Cosmides, L. (1992) The psychological foundations of culture. In: The adapted mind: Evolutionary psychology and the generation of culture, ed. J. H. Barkow, L. Cosmides \& J. Tooby. Oxford University Press. [rHR, DSW] (1996) Friendship and the banker's paradox: Other pathways to the evolution of adaptations for altruism. In: Evolution of social behavior patterns in primates and man. Proceedings of The British Academy, vol. 88, pp. 119-44, ed. W. G. Runciman, J. Maynard Smith \& R. I. M. Dunbar. Oxford University Press. [aHR]

Trivers, R. L. (1971) The evolution of reciprocal altruism. Quarterly Review of Biology 46:35-57. [HG, DR, JS]

Turiel, E. (1998) The development of morality. In: Handbook of child psychology: Social, emotional and personality development, vol. 3, ed. W. Damon \& N. Eisenberg. Wiley. [RAH]
Turner, J. C., Hogg, M. A., Oakes, P. J., Reicher, S. D. \& Wetherell, M. S. (1987) Rediscovering the social group: A self-categorization theory. Blackwell. [AAS]

Tversky, A. \& Kahneman, D. (1981) The framing of decisions and the rationality if choice. Science 211:453-58. [aHR]

Vallacher, R. R. \& Wegner, D. M. (1987) What do people think they're doing? Action identification and human behavior. Psychological Review 94:3-15. [AAS $]$

Van der Steen, W. J. \& Ho, V. K. Y. (2001) Methods and morals in the life sciences: A guide for analyzing and writing texts. Praeger. [WJvdS]

Van Lange, P. A. M. (1999) The pursuit of joint outcomes and equality in outcomes: An integrative model of social value orientation. Journal of Personality and Social Psychology 77:337-49. [MP]

Wagstaff, G. F. (2001) An integrated psychological and philosophical approach to justice: Equity and desert. Edwin Mellen Press. [GFW]

Wallach, M. A. \& Wallach, L. (1983) Psychology's sanction for selfishness: The error of egoism in theory and therapy. W. H. Freeman. [SK]

Wedekind, C. \& Braithwaite, V. A. (submitted) The long-term benefits of human generosity on indirect reciprocity. $[\mathrm{CW}]$

Wedekind, C. \& Milinski, M. (1996) Human cooperation in the simultaneous and the alternating Prisoner's Dilemma: Pavlov versus generous tit-for-tat. Proceedings of the National Academy of Sciences USA 93:2686-89. [CW] (2000) Cooperation through image scoring in humans. Science 288:850-52. $[\mathrm{CW}]$

Weirich, P. (2001) Decision space: Multidimensional utility analysis. Cambridge University Press. [PW]

(forthcoming) Economic rationality. In: Handbook of rationality, ed. A. Mele \& P. Rawling. Oxford University Press. [PW]

Wilson, E. O. (1975) Sociobiology: The new synthesis. Harvard University Press. [HM, DJZ]

Wilson, M. \& Daly, M. (1997) Life expectancy, economic inequality, homicide, and reproductive timing in Chicago neighborhoods. British Medical Journal 314:1271-74. [DSW]

Youniss, J. \& Yates, M. (1999) Youth service and moral civic identity: A case for everyday morality. Educational Psychology Review 11:361-76. [RAH]

Zahavi, A. (1995) Altruism as a handicap: The limitation of kin selection and reciprocity. Journal of Avian Biology 26:1-3. [CW]

Zizzo, D. J. (2000a) Money burning and stealing in the laboratory: How conflicting ideologies emerge. Department of Economics Discussion Paper No. 40, University of Oxford. http://www.economics.ox.ac.uk/Research/ working_papers.htm [DJZ]

(2000b) Relativity-sensitive behaivour in economics. Unpublished doctoral dissertation, University of Oxford. [DJZ]

(in press) Empirical evidence on interdependent preferences: Nature or nurture? Cambridge Journal of Economics. [DJZ]

Zuidema, W. (2003) How the poverty of stimulus solves the poverty of stimulus. In: Advances in Neural Information Processing Systems 15, ed. S. Becker, S. Thrun, \& K. Obermayer, MIT Press (forthcoming). http://arti.vub.ac.be/ jelle/research/zuidema02nips.pdf [WZ]

Zuidema, W. \& Hogeweg, P. (2000) Selective advantages of syntactic language: A model study. In: Proceedings of the $22^{\text {nd }}$ Annual Meeting of the Cognitive Science Society, pp. 577-82. Erlbaum. http://arti.vub.ac.be/ jelle/research/ cogsci2000.pdf [WZ] 